\title{
Norway spruce (Picea abies /L./ Karst.) health status on various forest soil ecological series in Silesian Beskids obtained by grid or selective survey
}

\author{
*Pavel Samec, Magda Edwards-Jonášová, Pavel Cudlín
}

Global Change Research Institute, Czech Academy of Sciences, Lipová 9, CZ-370 05 ČeskéBudèjovice, Czech Republic; e-mail:psamec@post.cz

\begin{abstract}
Samec P., Edwards-Jonášová M., Cudlín P. 2017: Norway spruce (Picea abies /L./ Karst.) health status on various forest soil ecological series in Silesian Beskids obtained by grid or selective survey - Beskydy, 10 (1, 2): 57-66

The values of characteristics of forest health status (FHS) depend on design of monitoring plot selection. The aim of the work was to compare the dependence of FHS on various ecological site conditions on research plots with different selection designs. The differences of Norway spruce (Picea abies /L./ Karst.) defoliation, discoloration and total damage variance were investigated in the Silesian Beskids (Czech Republic; 297 km²;3041067 m a.s.l.) during 1999-2008. FHS results on 187 plots at $400 \times 400$ m grid were obtained through routine methods according to EMEP-LRTAP. In addition, forest health status on 18 plots of selective survey design was obtained by estimation of defoliation and crown structure transformation. The comparison of ecological series proportion in individual survey designs was carried out through Mann-Whitney U-test, the comparison of health status feature occurrence in ecological series between different survey designs through analysis of variance. The survey design did not influence ecological series proportion, but influenced FHS feature variance. FHS features on sites of various ecological series have different rate of tree damage in individual survey designs. The selective survey significantly decreased data variance in contrast to low plot frequency.
\end{abstract}

Key words: spruce decline, survey design, defoliation, forest site ecological series

\section{Introduction}

Spruce health status differs among local growth conditions in areas under unspecific decline. Spruce decline in Central Europe manifests by needle loss, yellowing and decreased stand increment (Schultze et al. 1989). A series of stress responses due to multiple impacts of natural and/or anthropogenic stressors, leading to progressive forest health status deterioration and to stand dieback consequently, is a basic effect differentiating unspecific decline from other forest diseases (Manion 2003). The unspecific decline is followed by ecosystem stability decrease, a complex hierarchical process with various periods and spatial scales from several minutes (foliage) to decades (stands) (Larsen 1995).
Understanding of the environmental stress impact depends on the description of growth condition variability by suitable survey design. These designs can be generally divided into grid or selective designs. The grid design equally samples the whole area, where prevailing features are usually well characterized but local deviations need not to be representatively recorded (Mandallaz 2007). On the contrary, the selective design is focused on proportional recording of all mapped growth condition types. Credibility of the selection is conditioned by mapping scale and by derivation of relationship between area representation and selection frequency. The selection frequency in forest surveys is reliable 
at sampling of more than $90 \%$ of incident conditions (Fattorini et al. 2015). Selection of ideal survey design influences accuracy in estimation of relationships between forest stand status and growth conditions.

Grid design is a basic structure of forest inventory (Wright et al. 2000). The inventory is carried out on sample plots localized pseudo-randomly at grid cells. Distribution of one plot to every grid cell helps to keep statistical criteria of random selection and pseudo-replication restriction (Grafström et al. 2017). Nevertheless, recording of local deviations depends on grid size. Grid $2 \times 2 \mathrm{~km}$ was selected as feasible to realize for the area of whole Czech Republic and simultaneously usable for regional scale (e.f. Natural Forest Areas) (Černý et al. 2004). The variance of linear and non-linear variables at various scales is comparable through hierarchical grids of multiple spacious cells (Barabesi et al. 2015). Unequal variances distort the comparison of mean tree characteristic values obtained by field survey (Bošel'a et al. 2016).

Central-European cultural landscape is sufficiently characterized by a grid $\sim 500 \times 500 \mathrm{~m}$ (Lorenzová et al. 2013). Even so, the analysis of large-scale area, covered by relatively detailed grid, requires using of remote sensing facilities. The severity of field surveys enables to elaborate only middle-sized areas. That is why regional grid $400 \times 400 \mathrm{~m}$, used for field survey on nutrient content in the leaves, has been performed only in some forest areas (Reininger et al. 2011). The supra-national or national grids in the International Co-operative Programme (ICP) by EMEP-LRTAP, $16 \times 16 \mathrm{~km}$ and $8 \times 8 \mathrm{~km}$ respectively, used for forest status observation, records spruce stand representation similarly like selective surveys, but a bit higher than national inventory (cf. Fabiánek et al. 2004).

A selective design is usually related to specific aim of study, which needs to work either with a small number of variables on large area or with high variable number on small area. Disadvantages of these approaches are a decreased possibility to simulate difficult relationships in the first case and an impossibility to generalize small area due to pseudo-replication (Heikkinen 2006). The selective design is used for forest small basin monitoring and for increment modelling from permanent measurement plots (PMPs). Both monitoring systems are concentrated on spruce stands. Norway spruce proportion reaches up 50.6\% in the Czech Republic, but on national inventory plots it is only $44.1 \%$ and $55.7 \%$ on PMPs. Nevertheless, spruce stands form $>75 \%$ of pure single-storeyed stands. From this point of view, they are the most frequent stand type for monitoring (Ziche, Seidling 2010). However, unnatural stands do not enable sufficiently to evaluate correlations between site and community (Davi et al. 2005). This impossibility can be eliminated by comparison analysis between natural and unnatural stands under similar growth conditions. The comparison analysis describes correlation differences better than grid survey (Samec et al. 2012).

In this study, we compared the health status of Norway spruce (Picea abies /L./ Karst.) forest stands under different growth conditions, selected by different survey designs. The growth conditions were presented as forest type ecological series. Forest type is a spatial unit of permanent site properties enabling repeatable succession of the same plant community. Permanent site properties are manifested as local connections of climate, relief, bedrock and soil (Viewegh et al. 2003). Ecological series is one of the characteristic of the forest type including soil and relief properties. It is characterized by soil fertility, water availability and soil grain-size (Macků, Sirota 2009). Ecological series under homogeneous mesoclimate characterize forest growth conditions, undermining ecosystem dynamics and its ecological stability better than altitude (Novotný et al. 2016). Ecological stability has resistant and resilient components; defoliation values inform us about tree resistance, while values crown structure transformation inform about resilience (Cudlín et al. 2001, Polák et al. 2007). Because unnatural spruce stands have a weak proportional coupling with the site conditions, their stress response studied by different survey designs (grid and selective patterns) can indicate different values. In the paper we bring the comparison of both basic designs among health status of Norway spruce stands on various ecological series in climatically homogenous area.

\section{Material and methods}

Norway spruce (Picea abies /L./ Karst.) health status was compared on area of Jablunkov Forest District from the State Enterprise Forests of the Czech Republic between Silesian Beskids, Jablunkov Intermountains and from Ropice to Velký Polom massives in Moravian-Silesian 
Beskids (297 km²; 304-1067 m a.s.l.; 49.489$49.684 \mathrm{~N}, 18.595-18.859 \mathrm{E})$, where heavy unspecific spruce stand decline has occurred since 2005. Forest land of the investigated area reached up to $45 \%$. Norway spruce representation was $61 \%$.

To study the influence of site conditions on occurrence of Norway spruce stand damage in the whole Jablunkov Forest District, all forest stands with spruce proportion $>50 \%$ and older than 60 years were extracted from the Forest Management Plan (FMP), operating for the period 1999-2008 (Müllerová et al. 2009). The selection included 736 stands with summary area of $34.7 \mathrm{~km}^{2}$ (26\% of spruce occurrence in the Jablunkov Forest District). Their spruce stand health status was characterized by percentage of sanitary felling (SF) volume during whole 10 years of FMP functioning. All below mentioned research plots, selected by different design, were assigned to one of 736 FMP plot by their coordinates. This allowed obtain data about their SF rate.

Grid design data were taken firstly from national forest inventory (NFI) with grid $2 \times 2 \mathrm{~km}$. In the Silesian Beskids 34 circular plots $500 \mathrm{~m}^{2}$, sampled in 2001-2004, were found in the database. Overlay with FMP selection included 11 plots. The spruce health status was assessed on the base of defoliation and total stand damage. Stand damage value was calculated from the representation of trees with defoliation $\geq 40 \%$ and with the categories of severe mechanical damage and patogen occurrence (Jankovská, Štěrba 2007).

In addition, 187 circular plots $\left(1,000 \mathrm{~m}^{2}\right)$, consisted of, stands with spruce proportion $>80 \%$ and older than 40 years was established in a regional grid $400 \times 400 \mathrm{~m}$ in 2008 , the most closely to a grid cell intercept point. Health status was assessed by ground observation of the total defoliation, discoloration, needle class number, stem mechanical disruption and pest occurrence for all trees. Stand damage was classified according to percentage of damaged trees defoliated $>40 \%$ and/or with less than four needle classes and/or distinct mark of discoloration (Šrámek et al. 2008).

Selective design was focused on quantitative sampling of most wide-spread ecological series (ES) in the Silesian Beskids (Holuša 2004). The 18 plots $50 \times 50 \mathrm{~m}$ in pure simple-storeyed Norway spruce stands older than 40 years were established. The crown total defoliation and structure transformation among other features were assessed for 12 randomly selected trees, from which tree stress response was classified. The percentage of stand damage was calculated from the number of trees with crown total defoliation $\geq 40$ \% (Cudlín et al. 2010).

Comparison between grid and selective designs consisted of testing FHS feature differences among various growth conditions, characterized by ecological series according to Viewegh et al. (2003). The testing of differences in ecological series representation on selected plots was carried out through Mann-Whitney U-test (Zar 1994). Representation of ES was obtained for all research plots by vector overlay with the Regional Plan of Forest Development database according to Forest Management Institute Brandýs nad Labem (Samec 2009). Values of defoliation and total stand damage in grid and selective survey designs were compared between most frequently wide-spread ES through analysis of variance at $P<0.05$. Relationships among FHS of the compared survey designs and stand properties were tested by linear correlation. ES were transformed to ordinary scale using their buffering potential which classified their soil carrying capacity (Macků 2004).

Differences among FHS were discussed with selective comparison analysis of defoliation in 11 spruce forest stands excerpted from the National Forest Inventarization database, located at range of $559-1173 \mathrm{~m}$ a.s.l. on nutrient-rich (75\%), exposed (17\%) and waterlogged (8\%) sites (Samec et al. 2012) and with results of ICPmonitoring grid $8 \times 8 \mathrm{~km}$, represented by three plots at 340-630 m a.s.l. (Fabiánek et al. 2004).

\section{Results}

The representation of ecological series was similar among compared research plots selected by different pattern. Spruce stands occurred mostly on nutrient-rich sites (86-96\%); only plots selected by selection design were more frequently situated on waterlogged ecological series (Table 1). Nevertheless, the representation of FHS feature values in most wide-spread ecological series (ES) differed between individual plot selection designs. On the plots with regional grid pattern the highest mean defoliation occurred on maple sites (36\%) and the lowest on waterlogged sites (17\%), the highest discoloration rate and stand damage were recorded on exposed sites (47\%), and least damaged stands 
occurred on waterlogged sites (9\%). The lowest discoloration was obtained on maple sites (10 \%). Highest needle-class number occurred on waterlogged sites (Table 2). Concerning FMP data, sanitary fellings (SF) were mostly concentrated on floodplain (almost $300 \mathrm{~m}^{3} / \mathrm{ha}$ ) and acidic and nutrient-rich sites (> $100 \mathrm{~m}^{3} / \mathrm{ha}$ ) (Table 1). However, the most frequent SFs were registered on maple sites $\left(78 \mathrm{~m}^{3} / \mathrm{ha}\right)$ on plots selected by regional grid design (Table 2) and on nutrient-rich sites (167 $\mathrm{m}^{3} /$ ha) by selective design (Table 3 ).

Differences in FHS values among ecological series on selective design plots were less distinctive compared to regional grid design plots. On the other hand, defoliation mean values were higher on selective design plots than on grid design plots. Stand defoliation on nutrient-rich sites was averagely $35 \%$, on acidic $36 \%$ and $34 \%$ on waterlogged sites (Table 3). Although, FHS feature values differed, the large data variance caused insignificant differences in FHS among survey designs as well as among ecological series at $P<0.05$. Size of the variance was directly proportional to included plot number. Only design of plot selection factor got near to statistical significance (Table 4).

Damaged tree proportion on nutrient-rich sites was similar between selective and regional grid designs, but on waterlogged sites, it was markedly higher at selective survey than at grid survey. As the lowest defoliation and stand damage values were obtained on waterlogged sites, the worst FHS features were obtained on acidic sites at both selective and grid surveys (Tables 2 and 3). Crown transformation corresponded more with damaged tree representation than

Tab. 1: Forest type ecological series proportion (\%) including comparison between vector and field survey by Mann-Whitney's U-test and volumes of sanitary fellings (average \pm standard deviation) in ecological series.

\begin{tabular}{|c|c|c|c|c|c|}
\hline \multirow{2}{*}{$\begin{array}{l}\text { Ecological } \\
\text { series }\end{array}$} & \multicolumn{4}{|c|}{ Survey design } & \multirow{2}{*}{$\begin{array}{c}\text { FMP database } \\
\text { SF }\left(\mathrm{m}^{3} / \mathrm{ha}\right)\end{array}$} \\
\hline & FMP & NFI & grid & selection & \\
\hline Exposed & - & - & 1.06 & - & - \\
\hline Maple & 1.22 & 3.44 & 2.66 & - & $99.64 \pm 102.36$ \\
\hline Floodplain & 0.16 & 1.96 & 1.06 & - & $297.59 \pm 64.34$ \\
\hline Waterlogged & 0.79 & 1.96 & 2.13 & 11.76 & $89.03 \pm 92.71$ \\
\hline Nutrient-rich & 96.32 & 88.72 & 90.43 & 82.68 & $129.85 \pm 126.00$ \\
\hline Acidic & 1.51 & 3.92 & 3.21 & 5.56 & $142.07 \pm 207.46$ \\
\hline U-test & & 0.37 & 0.67 & 0.53 & \\
\hline $\mathbf{P}$ & & 0.72 & 0.50 & 0.59 & \\
\hline
\end{tabular}

FMP - forest management plan;NFI-national forest inventory; Grid-regional grid $400 \times 400 \mathrm{~m}$ design; Selection - selective design; SF - sanitary fellings; P - level of significance.

Tab. 2: Spruce health status features of grid designs of plot selection and their percentage of sanitary fellings (SF) according to Forest Management Plan (average \pm standard deviation).

\begin{tabular}{|c|c|c|c|c|c|c|}
\hline \multirow{2}{*}{$\begin{array}{l}\text { Ecological } \\
\text { series }\end{array}$} & \multirow{2}{*}{$\begin{array}{c}\text { Inventory } \\
\begin{array}{c}\text { Defoliation } \\
(\%)\end{array} \\
\end{array}$} & \multicolumn{5}{|c|}{ Regional grid } \\
\hline & & $\begin{array}{c}\text { Defoliation } \\
(\%)\end{array}$ & \begin{tabular}{|c|} 
Discoloration \\
$(\%)$
\end{tabular} & \begin{tabular}{|c|}
$\begin{array}{c}\text { Needle class } \\
\text { (years) }\end{array}$ \\
\end{tabular} & \begin{tabular}{|c|} 
Stand \\
damage (\%) \\
\end{tabular} & SF (m³/ha) \\
\hline Exposed & - & $20.43 \pm 18.29$ & $100.00 \pm 0.00$ & $4.80 \pm 1.82$ & $46.48 \pm 52.38$ & - \\
\hline Maple & $28.69 \pm 2.84$ & $35.81 \pm 16.52$ & $9.52 \pm 14.68$ & $4.59 \pm 0.99$ & $44.58 \pm 25.48$ & $78.08 \pm 55.58$ \\
\hline Floodplain & $25.22 \pm 0.57$ & $21.07 \pm 2.21$ & $50.00 \pm 70.71$ & $4.02 \pm 0.38$ & $40.43 \pm 19.96$ & - \\
\hline Waterlogged & $23.16 \pm 0.00$ & $16.86 \pm 14.23$ & $25.00 \pm 50.00$ & $6.42 \pm 0.80$ & $9.26 \pm 11.44$ & - \\
\hline Nutrient-rich & $25.76 \pm 2.58$ & $29.28 \pm 15.66$ & $35.16 \pm 44.01$ & $4.65 \pm 1.34$ & $41.48 \pm 32.79$ & $46.92 \pm 55.58$ \\
\hline Acidic & $25.84 \pm 5.46$ & $26.77 \pm 13.46$ & $40.87 \pm 54.01$ & $4.70 \pm 1.44$ & $49.20 \pm 39.67$ & $41.64 \pm 51.62$ \\
\hline
\end{tabular}

Inventory - data from National forest inventory. 
with defoliation. The transformation $>30 \%$ occurred on plots with damaged tree proportion $20 \%$ at least. Concerning the relationships between spruce health status, including percentage of sanitary felling, and ecological series buffering in individual survey designs, the linear correlation test revealed only almost statistically significant correlation between sanitary felling and ecological series ordered according their buffering capacity $(r=0.55$ at $P<0.07)$ for data provided by National Inventory of Forests and still weaker correlation for data from regional grid survey (tab. 5).

Tab. 3: Spruce health status features of selective design of plot selection and their sanitary fellings (SF) according to Forest Management Plan (average \pm standard deviation).

\begin{tabular}{l|c|c|c|c}
\hline \multirow{2}{*}{$\begin{array}{c}\text { Ecological } \\
\text { series }\end{array}$} & \multicolumn{2}{|c|}{ FHS (\%) } & \multicolumn{2}{c}{ Stand response (\%) } \\
\cline { 2 - 5 } & Defoliation & Transformation & Stand damage & SF $\left(\mathbf{m}^{\mathbf{3}} / \mathbf{h a}\right)$ \\
\hline Waterlogged & $33.55 \pm 2.65$ & $24.17 \pm 7.07$ & $33.00 \pm 0.00$ & - \\
Nutrient-rich & $35.21 \pm 3.93$ & $26.57 \pm 9.27$ & $36.93 \pm 23.05$ & $167.86 \pm 165.03$ \\
Acidic & $35.83 \pm 4.17$ & $35.83 \pm 11.84$ & $41.00 \pm 0.00$ & $104.59 \pm 0.00$ \\
\hline
\end{tabular}

Tab. 4: Analysis of variance on spruce health status features between survey designs and ecological series (ES).

\begin{tabular}{c|c|c|c|c}
\hline \multicolumn{1}{c|}{ Feature } & Effect & DF & F 0.05 & $\boldsymbol{P}$ \\
\hline \multirow{3}{*}{ Defoliation } & Survey & 2 & 1.74 & 0.18 \\
& ES & 2 & 0.20 & 0.82 \\
& Survey*ES & 4 & 0.09 & 0.99 \\
\hline \multirow{3}{*}{ Damage } & Survey & 2 & 0.32 & 0.73 \\
& ES & 2 & 0.57 & 0.57 \\
& Survey*ES & 4 & 0.38 & 0.82 \\
\hline
\end{tabular}

DF - degrees of freedom; F0.05 - Fischer-Snedecorov' test; P - level of significance.

Tab. 5: Linear correlations of spruce health status and ecological series in survey designs.

\begin{tabular}{l|c|c|c|c|c|c}
\hline \multirow{2}{*}{ Survey } & \multicolumn{2}{|c|}{ Defoliation } & \multicolumn{2}{c|}{ Stand damage } & \multicolumn{2}{c}{ Sanitary fellings } \\
\cline { 2 - 7 } & $\mathbf{r}$ & $\mathbf{P}$ & $\mathbf{r}$ & $\mathbf{P}$ & $\mathbf{r}$ & $\mathbf{P}$ \\
\hline FMP & - & - & - & - & 0.02 & 0.54 \\
Inventory & 0.01 & 0.79 & 0.00 & 0.96 & 0.55 & 0.07 \\
Regional grid & -0.04 & 0.84 & 0.02 & 0.93 & 0.20 & 0.16 \\
Selection & -0.14 & 0.83 & 0.06 & 0.86 & 0.16 & 0.56 \\
\hline
\end{tabular}

For explanation of survey design modes see table l. $\mathrm{r}$ - correlation coefficient (bolt significant dependence); P - level of significance. 
a) Spruce crown defoliation

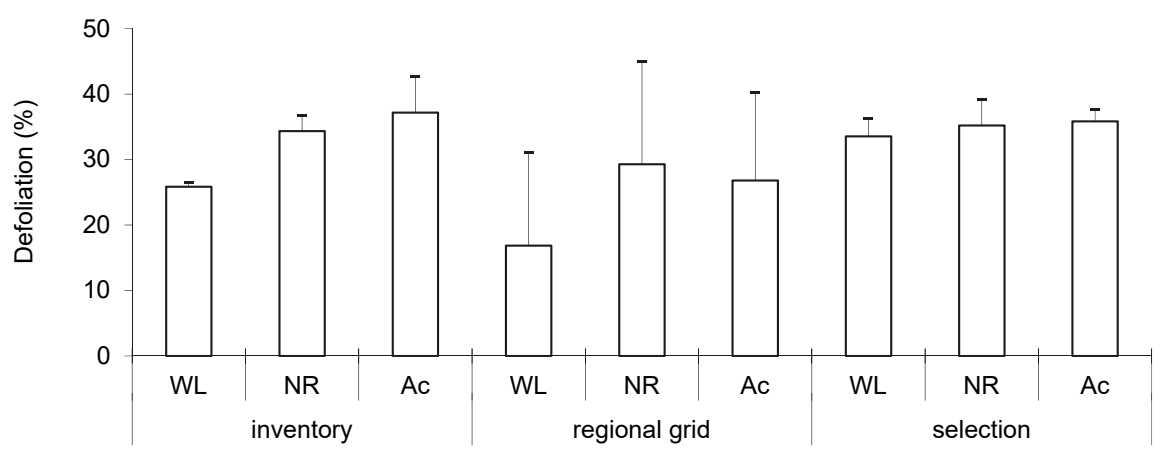

b) Spruce stand damage

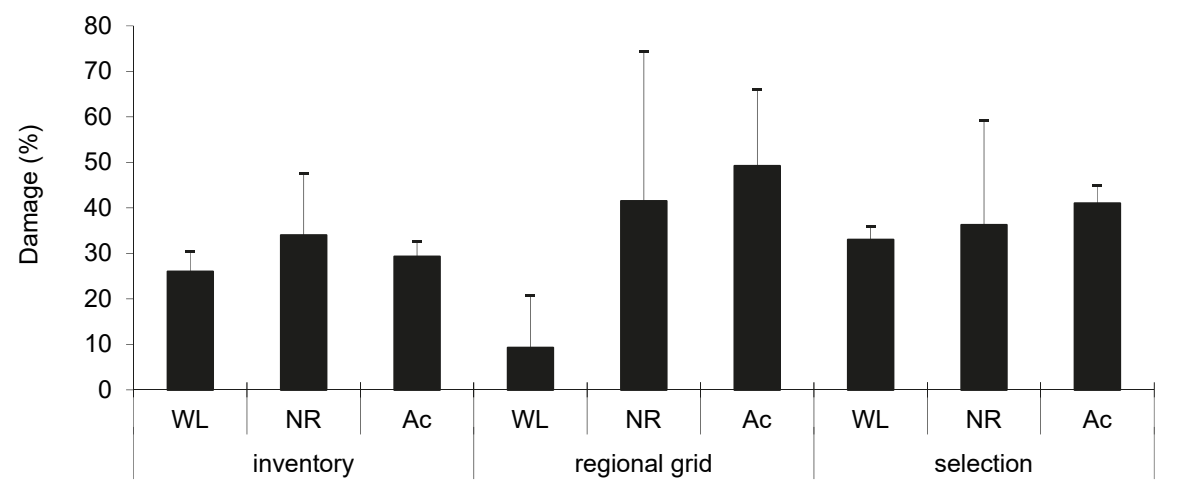

Fig. 1: Spruce defoliation (a) and stand damage (b) averages and standard deviations on most frequent forest site ecological series: WL-waterlogged; NR-nutrient-rich; Ac-acidic.

\section{Discussion}

Forest stands on plots selected by regional grid and selective designs have similar variance of observed values, if survey accuracy is indirectly proportional to survey frequency. A sufficiently detailed grid characterizes ecological series representation similarly like quantitative selection (Kovár 2001). However, total size of the investigated area, as well as a grid cell size, influence an integrity of studied growth conditions. National forest inventory (NFI) in the Beskids Mts. registered nutrient-rich, floodplain as well as acidic sites, although the selection design of spruce stand plots included also maple sites and lower proportion of water-influenced and acidic sites. Compared to NFI, regional grid registered exposed sites and lower proportion of water-influenced sites (Table 1). The selective design of research plots was specifically focused on ecologically similar stands, differing mostly by tree damage rate; therefore it consists only of one prevailing and two marginally represented ES.

Plots selected by variously detailed grid patterns characterize differences of forest health status on various ecological series differently, but plots from selective patterns characterize them seemingly similarly. Average spruce stand defoliation had lower variance on nutrient-rich sites at NFI-grid research plots compared to defoliation on regional grid plots. Defoliation on acidic sites was lower than on nutrient-rich sites on regional grid plots but defoliation on maple sites was simultaneously higher on plots of both grid patterns. Spruce defoliation on acidic sites at NFI-grid was averagely $<26 \%$, but it was $>28 \%$ on maple sites (Jankovská, Štěrba 2007). 
Clear conjuction between ecological series and forest health status deterioration does not exist. Site does not influence forest health status evenly, but tree defoliation and discoloration are influenced differently (Vacek et al. 2009). Soil water fluctuation on waterlogged sites increases defoliation more than on unwaterlogged sites, but it simultaneously encourages forming of necroses in assimilation aparatus (Král et al. 2015). In contrast, conjuction between exposed ecological series and summit terrain does not encourage defoliation, but it intensity forest dynamics due to full-area disturbance or particular tree dieback (Králíček et al. 2017).The forest stands from selective survey design were characteristic by lower variance of defoliation, as well as of damaged tree proportion compared to stands at regional grid. Defoliation was not a feature preconditioning the spruce stand damage. Spruce defoliation and stand damage level were lower on waterlogged sites compared to another ecological series. During comparison between spruce and beech stands, spruce defoliation was $<4 \%$ on waterlogged sites and $<24 \%$ on exposed sites, although nutrient-rich sites were characterized by spruce defoliation $>30 \%$ (Samec et al. 2012).

The relationship of ecological series and FHS variability signalizes usability of differentiated approach in observing, but this means simultaneously the need to change observed features to characterize better specific influences. Nutrient-rich sites in Beskids are often characteristic by higher spruce defoliation, because they are more exposed to drought (Novotný et al. 2016). Spruce defoliation on nutrient-rich sites increased from $9 \%$ in 1986 to $30 \%$ in 2003 despite of acid deposition decrease. Acidic and floodplain sites were characteristic by spruce defoliation $21 \%$ in 1986, but its level does not exceed $30 \%$ even during dry episodes (Fabiánek et al. 2004). Nutrient-rich sites are exposed to faster soil organic matter decomposition, which eliminates soil water-holding capacity. The observation of specific influences on FHS is based on connection of data about soil organic matter and ecosystem water content (Samec et al. 2012). Although support for the observation of ecosystem water content by remote-sensing relates with detailed grid use, the observation of soil properties under stand cover needs selection of good representative pits (Ziche, Seidling 2010; Fattorini et al. 2015; Brovkina et al. 2017).

\section{Conclusion}

Ecological series affected slightly spruce stand health status. Survey design did not significantly influence ecological series representation on selected plots, but it influenced result variance of studied features. Similar variance of forest health status feature between grid and selective survey designs was conditioned by an indirect proportion between accuracy and frequency of the survey. Enough detailed grid characterizes growth conditions directly proportionally to the size of the observed area, but more detailed selective survey significantly decreases data variance in contrast to markedly low frequency. The relationship of ecological series and variance of forest health status feature signalizes a need to change features observed at grid survey to characterize better specific influences.

\section{Acknowledgement}

The authors gratefully acknowledge the support by the Project LO1415 NPU I CzechGlobe 2020 and Project No. LD 15044 of the Ministry of Education, Youth and Sports of the Czech Republic.

\section{Literature}

Barabesi, L., Fattorini, L., Marcheselli, M., Pisani, C., Pratelli, L. 2015: The estimation of diversity indexes by using stratified allocations of plots, points or transects. Environmetrics, 26: 202-215.

Bošela, M., Redmond, J., KuČera, M., Marin, G., Adolt, R., Gschwantner, T., Petráš, R., Korhonen, K., Kuliešis, A., KulboKas, G., Fischer, C., LANZ, A. 2016: Stem quality assessment in European National Forest Inventories: an opportunity for harmonised reporting? Annals of Forest Science, 73: 635-648.

Brovkina, O., Cienciala, E., Zemek, F., Lukeš, P., FABIÁNEK, T., Russ, R. 2017: Composite indicator for monitoring of Norway spruce decline. European Journal of Remote Sensing, 50: 550-563.

Cudlín, P., Müllerová, T., Edwards-Jonášová, M., Vávrová, E., Chmelíková, E., Včeláková, R., Plch, R., Holub, F. 2010: Regenerační procesy v rozpadávajcích se smrčinách - případová studie v modelovém území Šadibolovci (Kysuce). In: KonopKA, B. (ed.), Výskum smreč́n destabilizovaných škodlivými činitel'mi. Národné lesnícke centrum, Zvolen, p. 217-226. 
Cudlín, P., Novotný, R., Moravec, I., Chmelíková, E. 2001: Retrospective evaluation of the response of montane forest ecosystems to multiple stress. Ekológia (Bratislava), 20: 108-124.

Černny, M., Zahradníček, J., PaŘez, J., Russ, R., TATARINOV, F. 2004: Metodika tvorby lesního hospodárského plánu na podkladè provozní inventarizace. MŽP, Praha. 215 pp.

Davi, H., Dufrêne, E., Granier, A., Le Dantec, V., Barbaroux, C., Francois, C., Bréda, N. 2005: Modelling carbon and water cycles in a beech forest Part II: Validation of the main processes form organ to stand scale. Ecological Modelling, 185: 387-407.

FabiáneK, P., Henžlík, V., Vančura, K. 2004: Development of forest stands condition and its monitoring in the Czech Republic. Journal of Forest Science, 50: 514-519.

Fattorini, L., Corona, P., Chirici, G., Pagliarella, M.C. 2015: Design-based strategies for sampling spatial units from regular grids with applications to forest surveys, land use, and land cover estimation. Environmetrics, 26: 216-228.

Grafström, A., Schnell, S., SaArela, S., Hubbell, S.P., Condit, R. 2017: The continuous population approach to forest inventories and use of information in the design. Environmetrics, 28: e2480.

HeIKKINEN, J. 2006. Assessment of Uncertainty in Spatially Systematic Sampling. In: KanGAS, A., Maltamo, M. (eds.), Forest Inventory, Methodology and Applications. Springer Verlag Jena: 155-176.

HolušA, J. 2004: Health condition of Norway spruce Picea abies (L.) Karst. stands in the Beskid Mts. Dendrobiology, 51 Supplement: 11-15.

JANKOVSKÁ, Z., ŠTĚrBA, P. 2007: National Forest Inventory in the Czech Republic 2001-2004. Introduction, Methods, Results. Forest Management Institute Brandýs nad Labem. 224 pp.

KovÁr̆, P. 2001: Geobotanika (Úvod do ekologické botaniky). Karolinum, Praha. 123 pp.

KRÁL, J., VACEK, S., VACEK, Z., ŠTEFANČÍK, I. 2015: Structure, development and health status of spruce forests affected by air pollution in the western Krkonoše Mts. in 1979-2014. Lesnický časopis - Forestry Journal, 61: 175-187.

Králíček, I., VAcek, Z., VAcek, S., Putalová, T. 2017. Dynamics and structure of mountain autochthonous spruce-beech forests: Impact of hilltop phenomenon, air pollutants and climate. Dendrobiology, 77: 119-137.
LARCHER, W. 1994: Ökophysiologie der Pflanzen: Leben, Leistung und Stressbewältigung der Pflanzen in ihrer Umwelt. Ulmer, Stuttgart.

LARSEN, J.B. 1995: Ecological stability of forests and sustainable silviculture. Forest Ecology and Management, 73: 85-96.

Lorenzová, E., Frélichová, J., Nelson, E., VAČKÁR̆, D. 2013: Past and future impacts of land use and climate change on agricultural ecosystem services in the Czech Republic. Land Use Policy, 33: 183-194.

MAcкŮ, J. 2004: Klasifikace ekotopu v lesnické typologii. In: Polehla P. (ed.), Hodnocení stavu a vývoje lesních geobiocenóz. MZLU v Brně, p. 169-175.

MackUீ, J., Sirota, I. 2009: Ecological Series of Forest Stands. 1:500000. In: HrČIANOvÁ, T., MackovČin, P., Zvara, I. (eds.), Landscape Atlas of the Czech Republic. Ministry of Environment, Silva Tarouca Research Institute for Landscape and Ornamental Gardering, Prague: 161.

Mandallaz, D. 2007: Sampling Techniques for Forest Inventories. Chapman and Hall/CRC Press. 272 pp.

Manion, P.D. 2003: Evolution of Concepts in Forest Pathology. Phytopathology, 93: 1052-1055.

Mooney, H.A., Winner, W.E., Pell, E.J. 1991: Responses of Plants to Multiple Stresses. Academic Press, San Diego, 422 p.

Müllerová, T., Cudlín, P., Žid, T., Čermák, P., RYBníČEK, M., KolÁŘ, T., KoŇAsová, E. 2009: Relationship between Crown Status and Radial Increment of Norway Spruce Forest Stands under Stress Impacts in the Silesian Beskids Mts. In: Pribullová, A., Bičárová, S. (eds.), Sustainable Development and Bioclimate. Geophysical Institute of the Slovak Academy of Sciences and Slovak Bioclimatological Society of the Slovak Academy of Sciences, Stará Lesná, p. 109-110.

Novotný, R., Buriánek, V., Šrámek, V., HŮnová, I., SKoŘepová I., Zapletal, M., LoMsKÝ, B. 2016: Nitrogen deposition and its impact on forest ecosystems in the Czech Republic - change in soil chemistry and ground vegetation. iForest Biogeosciences and Forestry, 10: 48-54.

Polák, T., Cudlín, P., Moravec, I., Albrechtová, J. 2007: Macroscopic indicators for the retrospective assessment of Norway spruce crown response to stress in the Krkonoše Mountains. Trees, 21: 23-35.

Reininger, D, Fiala, P, SAmeK, T. 201l: Acidification of forest soil in the Hrubý Jeseník region. Soil and WaterResearch, 6: 83-90. 
SAMEC, P. 2009. Revize biogeografické rajonizace pufračních schopností lesních půd. Acta Musei Beskidensis, 1: 1-22.

SAMec, P., TuČek, P., Bojko, J., JanošKa, Z., RYchtecKá, P., HÁJEK, F., Zapletal, M., Sirota, I., MikLoš, L., MLČOUŠKOVÁ, P., Zeman, M., SMeJKAL, J., Mach, S., PodrácKá, O. 2012: Modelování ruistových podmínek lesio $v$ České republice. Univerzita Palackého v Olomouci. 312 pp.

Schultze, E.D. 1989: Air pollution and forest decline in a spruce (Picea abies) forest. Science, 244: 776-783.

Šrámek, V., Vejpustrová, M., Novotný, R., HeLLEBRANDOVÁ, K. 2008: Yellowing of Norway spruce stands in the Silesian Beskids - damage extend and dynamics. Journal of Forest Science, 54: 55-63.

Vacek, S., Hejtman, M., Semelová, V., Remeš, J., PodrÁZsKÝ, V. 2009: Effect of soil chemical properties on growth, foliation and nutrition of a Norway spruce stand affected by yellowing in the Bohemian Forest Mts., Czech Republic. European Journal of Forest Research, 128: 367-375.

Viewegh, J., Kusbach, A., Mikeska, M. 2003: Czech forest ecosystem classification. Journal of Forest Science, 49: 85-93.

Wright, H., Atkinson, M., Baker, N., Healey, J.R. 2000: Documentation of UK holdings of growth and yield, inventory and other data from tropical forests. Final technical report. Oxford Forestry Institute, Oxford. $79 \mathrm{pp}$.

ZaR, J. 1994: Biostatistical Analysis. Prentice Hall Int., New Jersey. 663 pp.

Ziche, D., Seiduing, W. 2010: Homogenisation of climate time series from ICP Forests Level II monitoring sites in Germany based on interpolated climate data. Annals of Forest Science, 67: 804. 